\title{
Dime con qué juegas y te diré quién serás. Análisis de campañas navideñas de juguetes para niños y niñas en televisión de señal abierta en Lima (2011-2012)
}

Recibido: 28 de septiembre de 2012

Aceptado: 30 de abril de 2013

Publicado: 29 de noviembre de 2013
Héctor Mendoza Cuéllar

hector.mendoza@upc.edu.pe

Universidad Peruana de Ciencias Aplicadas

Resumen: El presente artículo de investigación plantea describir los roles de género propuestos a niños y niñas desde la publicidad de juguetes en Navidad a través de la televisión de señal abierta en Lima. Estos mensajes establecen contenidos que llevan a la adopción de roles de género estereotipados desde edades muy tempranas, los cuales son perennizados a lo largo de la vida. Este artículo se ha trabajado bajo un enfoque multidisciplinario y desde una perspectiva cuantitativa y cualitativa. Se realizó el análisis del mercado de juguetes en Lima, el número de spots difundidos durante la campaña navideña, para luego seleccionar los spots con mayor emisión y analizar qué representaciones de género proponían. Las distintas y complementarias miradas buscan comprender esta realidad, así como evidenciar la forma generalizada de llevar estas campañas para proponer nuevos caminos en la construcción de una sexualidad más equitativa desde la publicidad.

Palabras clave: Publicidad, juguetes, Navidad 2011-2012, roles hombre y mujer en publicidad, educación y género en publicidad, machismo, feminismo, estereotipos.

Abstract: This article presents research describing gender roles offered to boys and girls from Christmas toy advertising through broadcast television in Lima. These messages provide content that lead to the adoption of stereotypical gender roles from an early age, which are perpetuated throughout life. This article has been worked on a multidisciplinary approach and from a quantitative and qualitative perspective. Analysis was performed first toy market in Lima, the number of spots broadcast during the Christmas season, and then select the most emission spots and analyze how gender representations proposed. The different and complementary looks seek to understand this reality and how widespread 
evidence to bring these campaigns to propose new ways to build more equitable sexuality advertising.

Key words: Christmas Toys, Advertising 2011-2012, Male and Female Roles in Advertising, Education and Gender in Advertising, Sexism, Feminism, Stereotypes.

\section{Introducción}

Huizinga (2000) define el juego como una acción u ocupación libre que se desarrolla dentro de unos límites temporales y espaciales determinados, según reglas absolutamente obligatorias, aunque libremente aceptadas, que tiene su fin en sí misma y va acompañada de un sentimiento de tensión, alegría y de la conciencia de ser de otro modo en la vida corriente. El juguete, de otro lado, es considerado un objeto atractivo con el que se entretienen los niños y las niñas. Así, el juego puede desarrollarse perfectamente sin que sea imprescindible la presencia de un objeto (juguete). Sin embargo, en origen, el juguete precisaba de un juego donde poder utilizarse (Pérez, 2010).

¿Cuál es más importante? Esa discusión no es la finalidad de este artículo. Más aún considerando que hoy en día la relación juego y juguete ha cambiado. Los avances tecnológicos han otorgado al juguete mayor primacía que al juego, convirtiéndolo en un producto comercial con lo que ello puede implicar (ibídem). Por ejemplo, desarrollo de series de televisión, mercadería afín (merchadising), publicidad que promocione todos estos juguetes y accesorios para que los niños los deseen y se los pidan a sus padres, etc.

A partir de aquí pensemos, ¿qué relación puede establecer un niño con su juguete? Quizá piense que este objeto solo sirve para jugar y nada más, pero si ha observado las entregas de Toy Story su opinión puede cambiar radicalmente. El juguete puede convertirse en el centro del universo de muchos niños, en su compañero fiel y su posesión más valiosa.

De otro lado, desde una mirada más adulta, el juguete puede ser considerado una herramienta mediante la cual el niño exterioriza sus sueños y fantasías. Del mismo modo, puede decirse que se trata de un lente con el cual interpreta su realidad cotidiana o los elementos que más le impresionan de ella. A grandes rasgos, podría decirse que el niño(a) recibe múltiples influencias y mensajes. Su familia, amigos, escuela, la calle y los medios de comunicación le van indicando una serie de comportamientos que se esperan de él o ella, con los cuales irá construyendo su propia identidad. La primera pregunta que valdría hacerse es qué mensajes emiten los medios de comunicación, y específicamente la publicidad, en cuanto a la asignación de comportamientos para los niños y niñas.

Alfaro (2003 y 2006) refiere que la programación de los canales de televisión (de señal abierta y cable) ofrece series, dibujos animados, telenovelas que describen patrones de conducta que se esperan cumplan hombres y mujeres en la sociedad. Dentro de este razonamiento, podemos observar los spots de publicidad. En el caso puntual de los juguetes, estos suelen ser tamizados bajo un halo de "inocencia". Pocas personas, al menos 
en nuestro mercado, han analizado el tipo de imágenes y las representaciones que pueden darse de hombres y mujeres desde las campañas de juguetes para niños en Navidad.

Navidad es una época muy particular. Para algunos es sinónimo de buenos deseos, paz y amor para todos. No obstante, hay diversas voces que consideran que estas festividades se han convertido en una fecha de mercantilismo donde "lo que gastas representa cuánto te importo". Según cifras de la consultora GFK Conecta, se esperaba que el gasto de los limeños en la Navidad del 2012 llegase a 1,263 millones de soles (25\% más que el año 2011), lo cual estaría respaldado por una serie de ofertas de diversos productos y servicios que llevarán a una inversión promedio de 200 soles por persona $^{1}$ (ápud Cabanillas, 2012).

Los niños observan los spots de televisión donde se promocionan los juguetes para dicha temporada. Siguiendo la lógica de la comunicación publicitaria, estos mensajes deben ser construidos a partir de realidades recogidas desde comportamientos observados en los niños y niñas. Vale decir: los creativos emiten mensajes que hagan que los pequeños se interesen en los juguetes y así les pidan a sus padres que les compren dichos objetos.

Estos spots pueden usar ciertos objetos, colores, temáticas, escenarios, personajes, etc. Y proponer, de manera consciente o no, modelos de comportamiento a los niños y niñas. De este modo, se podría perennizar ideas sobre los objetos (juguetes) con los que debe jugar un niño y una niña; lo cual se instalará en ellos y los acompañará en sus razonamientos adolescentes, adultos y quizá sea transmitido cuando se conviertan en padres y madres.

El presente artículo expondrá qué tipos de representaciones de género pueden construirse a través de la publicidad de los juguetes expuestas en las Navidades de 2011 y 2012. Para ello, en primer lugar, se examinará el mercado de venta de juguetes y se complementará con la revisión de las cifras de los spots emitidos en las campañas navideñas del 2011 y 2012, específicamente en televisión de señal abierta. Para fines del análisis, es importante centrarse en un número de años específico. Dado que no hay investigaciones referidas a nuestra realidad, se considera válido el trabajar desde aquellos recuerdos más cercanos. Por ello, analizar las campañas publicitarias de juguetes de los años 2011 y 2012 permitirá al lector activar recuerdos cercanos que también contribuirán en la lectura que pueda hacer de este trabajo.

En segundo lugar, se abordarán las representaciones de género que se desarrollan en los spots en publicidad y específicamente en los de estas campañas. Para ello se recurrirá al trabajo desarrollado por Ferrer (2007) respecto a la clasificación de los spots de juguetes en Navidad, que nos permitirá tener un patrón para desplegar el análisis de casos y apoyarnos en las perspectivas de género de la sociedad limeña desde los medios, desarrollado por Alfaro (2003 y 2006), así como la mirada en los roles de género asumidos por hombres y mujeres en autores como Badinter (1994) y Callirgos (1998).

1 Con todo lo que esto puede significar en un país con tantas diferencias como el nuestro. Pese a lo que digan las cifras, hay personas que gastan mucho más de 200 soles por regalo y otros que simplemente no pueden comprarlos, ya que sus prioridades están abocadas a cubrir sus necesidades básicas. 
En tercer lugar, se analizarán los comportamientos de los grupos sociales, cómo adquieren sus comportamientos, cómo se transmiten, se perennizan y se puede luchar contra ellos. Entre los autores que revisaremos están Bordieu (1988) y Touraine (1969).

\section{Objetivos}

Para el desarrollo de dicha pregunta, se establece el siguiente objetivo general y los consiguientes objetivos específicos:

\section{Objetivo general:}

- Describir las representaciones de género que se transmiten en los spot de juguetes a los niños y niñas en Lima Metropolitana.

\section{Objetivos específicos:}

- Describir las construcciones de género que se expresan en las campañas navideñas en los años 2011 y 2012.

- Comparar las representaciones que expresan las campañas navideñas de juguetes para niños y niñas.

- Establecer si existe algún tipo de influencia en la construcción de género desde las campañas de juguetes en Navidad.

\section{Metodología}

La investigación implica el desarrollo de una metodología compuesta por la revisión de diversas fuentes de aspecto multidisciplinario como la sociología, la psicología, género y comunicación.

Esta investigación contará, además, con un enfoque cualitativo pues se busca analizar las representaciones sociales de género que pueden hallarse a través de los spots publicitarios de juguetes para niños transmitidos en televisión de señal abierta. El primer elemento de análisis es la revisión de las campañas publicitarias de las Navidades del 2011 y 2012 para hallar patrones comunes. En este caso, se analizará el monto de la inversión publicitaria, los horarios y programas donde fueron emitidos los spots y el anunciante.

Un segundo elemento de análisis será la revisión de trabajos que hayan realizado experiencias similares, como por ejemplo el trabajo de Ferrer (2007), que analiza los spots de juguetes de televisión en España y el análisis de publicidad peruana y estereotipo de género realizado por Alfaro (2003 y 2006) referido a la interpretación e influencia que pueden tener los programas que se emiten en la televisión y la publicidad tanto en mujeres como en niños, niñas y adolescentes.

Estos trabajos permitirán establecer los criterios para la selección de spots, que será el tercer elemento de análisis. Se realizará una muestra que tendrán las siguientes características: 
- Roles de género asignados a niños y niñas en los spots.

- Tipo de ambiente donde se desarrolla la historia.

- Uso del juguete que hace el niño(a) del juguete.

- Grado de realismo del spot con el juguete.

Un cuarto elemento será la lectura que se pueda realizar de los reportajes emitidos por los magazines dominicales y noticieros sobre juguetes, estableciendo desde el lenguaje y las imágenes qué tipo de juguetes se ofrece, costos, comportamientos que muestran a los niños(as) que aparecen en el reportaje.

\section{Hipótesis de trabajo}

Los spots publicitarios de juguetes emitidos en las campañas navideñas en televisión de señal abierta exhiben estereotipos de género sobre las conductas que deben esperarse de hombres y mujeres. Dichos estereotipos promueven conductas aceptadas y castigan aquellas que se alejan de los patrones establecidos con anterioridad y marginan a los niños y padres que van contra dichas normas.

\section{Análisis de las campañas navideñas}

Diversas campañas en televisión están construidas bajo el precepto que los niños aprenden sus conductas observando a los adultos. Por ejemplo, la campaña "Los niños hacen lo que ven" (figura 1) muestra comportamientos poco deseables de los adultos como arrojarle piedras a los animales, gritar de manera prepotente por un mal servicio, golpear un teléfono público, arrojar basura en la calle, etc. Siguiendo esta línea, la campaña "El reclamo de los niños incómodos" (figura 2) no solo hace hincapié en estas conductas no deseables, sino que expone delitos que, al parecer, se han vuelto cotidianos para el poblador de a pie en México (asaltos, secuestros, corrupción de funcionarios, trata de personas), lo cual es "retratado" por los niños que lo observan y da a entender que ellos están cansados de tener que vivir en un país con esas características.

Figuras 1 y 2: Campañas "Los niños hacen lo que ven" y "El reclamo de los niños incómodos".
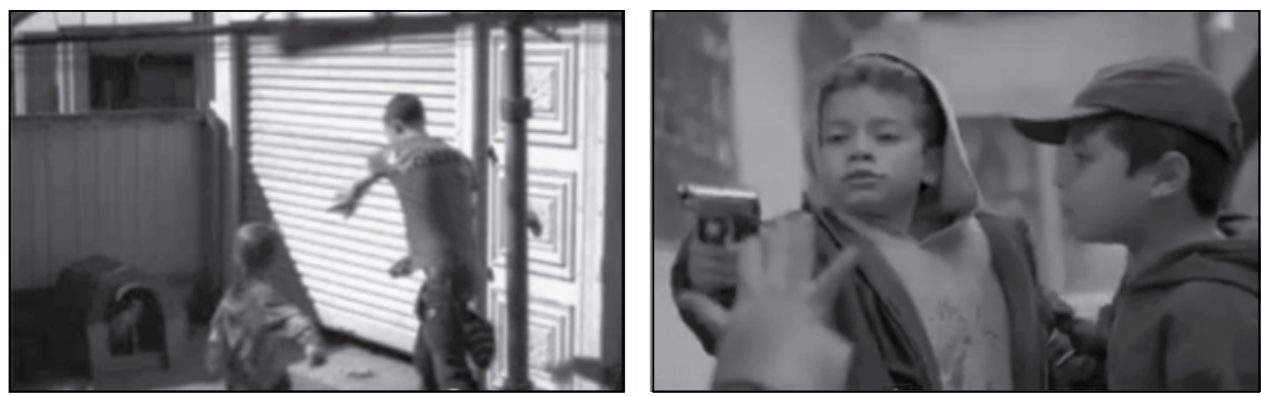

Fuente: YouTube (2008 y 2012d). 
Al examinar estos spots pareciese que los aprendizajes y perpetuación de comportamiento en los niños fuesen "naturales". Sin embargo, no es así. Los niños son seres en proceso de formación. La familia, la escuela y la televisión se convierten en ventanas desde las cuales miran lo que uno es y puede ser ( $c f$. Alfaro 2006: 7). A estas ventanas podría agregarse también la publicidad, los juegos, los juguetes, la ropa, accesorios en el vestir, etc.

Los estudios que se centran en la publicidad dirigida a niños son muy numerosos. Ferrer (2007: 136) retoma los postulados de Bringué y Juan de los Ángeles, quienes clasifican las investigaciones en cuatro etapas cronológicas, desde los años cincuenta a los ochenta, donde se pueden observar los efectos de la televisión en la conducta, así como los efectos indirectos en el niño, los efectos físicos, los estereotipos en la televisión y, por último, enfoques con posturas menos radicales (ibídem). Ello hace mirar con interés el binomio publicidad y juguetes: ¿Qué tipo de relación establece el niño con su juguete? ¿Qué tipo de representaciones de género se observa en los spots de juguetes de Navidad en la televisión de señal abierta en Lima? Empecemos por la primera pregunta.

\subsection{Por sus juguetes los conocerás}

El fotógrafo Gabriele Galimberti realizó un trabajo de 18 meses retratando a niños de diversos países con sus juguetes. En su opinión, los niños juegan de maneras distintas. En los países más ricos, los niños fueron más reacios en compartir sus juguetes; mientras que en los países más pobres, fueron más rápidos en prestarle sus juguetes. Desde su perspectiva, para estos últimos importaba más la interacción con el otro. No obstante, hay similitudes como por ejemplo el uso de dinosaurios entre un niño de Texas y una niña de Malawi.

Figuras 3 y 4: Orly (EE. UU.) y Chiwa (Malawi) comparten la idea de que los dinosaurios los protegen de los peligros de la noche.
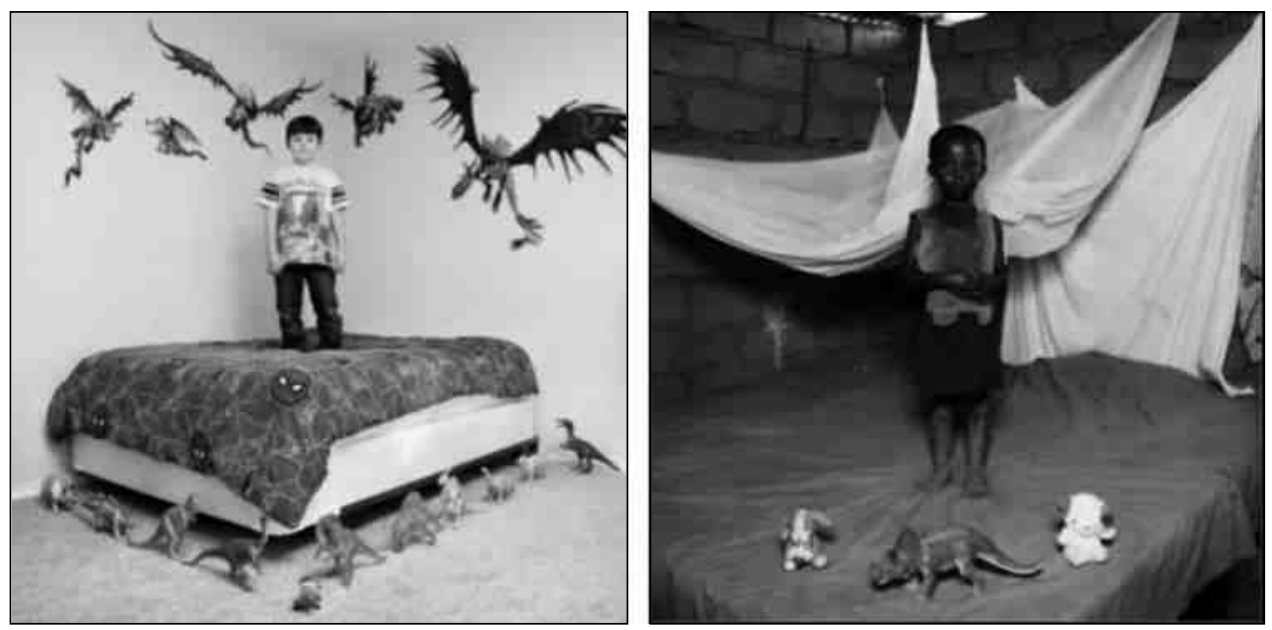

Fuente: Galimberti (2013). 
Molina (2008) retoma el trabajo de Piaget respecto a la clasificación de los juegos, los cuales pueden categorizarse en cuatro tipos: motor, simbólico, de reglas y de construcción. De estos, el de tipo simbólico nos ofrece un enfoque muy interesante para esta investigación pues desarrolla situaciones y personajes como si estos estuvieran presentes. Asimismo, permite al infante dominar a su antojo una realidad en la que se ve continuamente dominado y, lo más importante, más allá de imitar personas, imita el rol social que el niño define por las acciones más características y, con frecuencia, exageradas que observa (Molina, 2008).

Bajo esta misma lógica, y profundizando en el tema, una niña de una familia acomodada en Mumbai (India) le encanta jugar al Monopoly, porque le gusta la idea de construir casas y hoteles (figura 5), mientras que un niño de una zona rural de México ama los camiones porque a menudo los ve atravesar su pueblo hasta la próxima plantación de azúcar todos los días (figura 6). Del mismo modo, un niño en Letonia juega con coches en miniatura, ya que su madre era una taxista y la hija de un campesino italiano tiene una variedad de rastrillos de plástico, azadas y palas (figura 7).

Figuras 5, 6 y 7: Juguetes de Shaira (India), Abel (México) y Alessia (Italia).
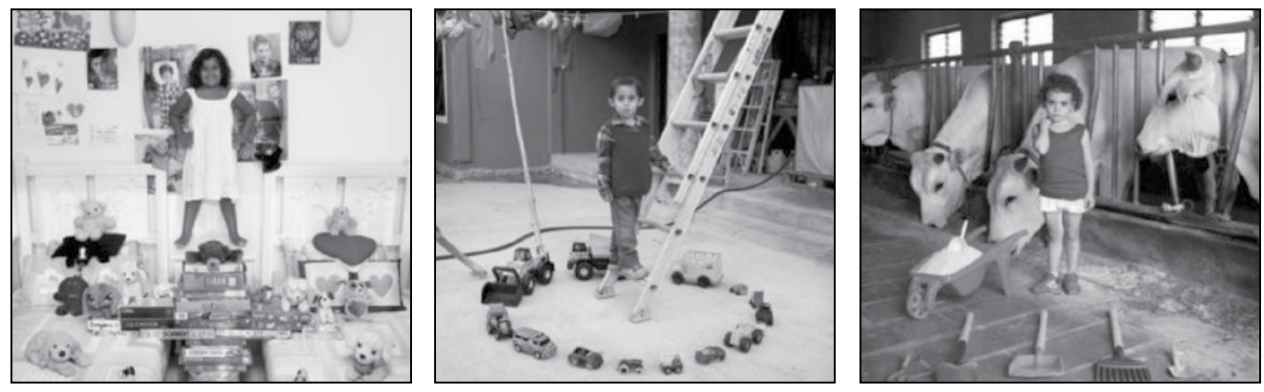

Fuente: Galimberti (2013).

Dentro de este trabajo, de manera intencional o no, se puede observar que los juguetes de las niñas, en su mayoría, suelen ser muñecas, juegos de mesa y peluches que pueden asociarse a situaciones como la maternidad, las tareas domésticas, la belleza y la fragilidad. Por otro lado, los juguetes que los niños suelen presentar son armas en miniatura, carros o motos a escala y bloques de construcción que suele asociarse a destrezas físicas, fuerza, astucia y poder. También es importante señalar que, en algunos casos, las niñas tenían muñecos de la categoría acción, aunque esto se observa en países pobres, lo cual puede deberse a que es un juguete donado y no comprado. Sin embargo, esto va vislumbrando que las niñas pueden, y lo hacen, jugar con juguetes de niño sin ninguna complicación, ¿sucederá lo inverso? Lo revisaremos más adelante. 
Figuras 8 y 9: Niñas con muñecas (Julia, Albania) y niños con armas en miniatura

(Pavel, Ucrania) suelen ser las propuestas más comunes ofrecidas a los pequeños.
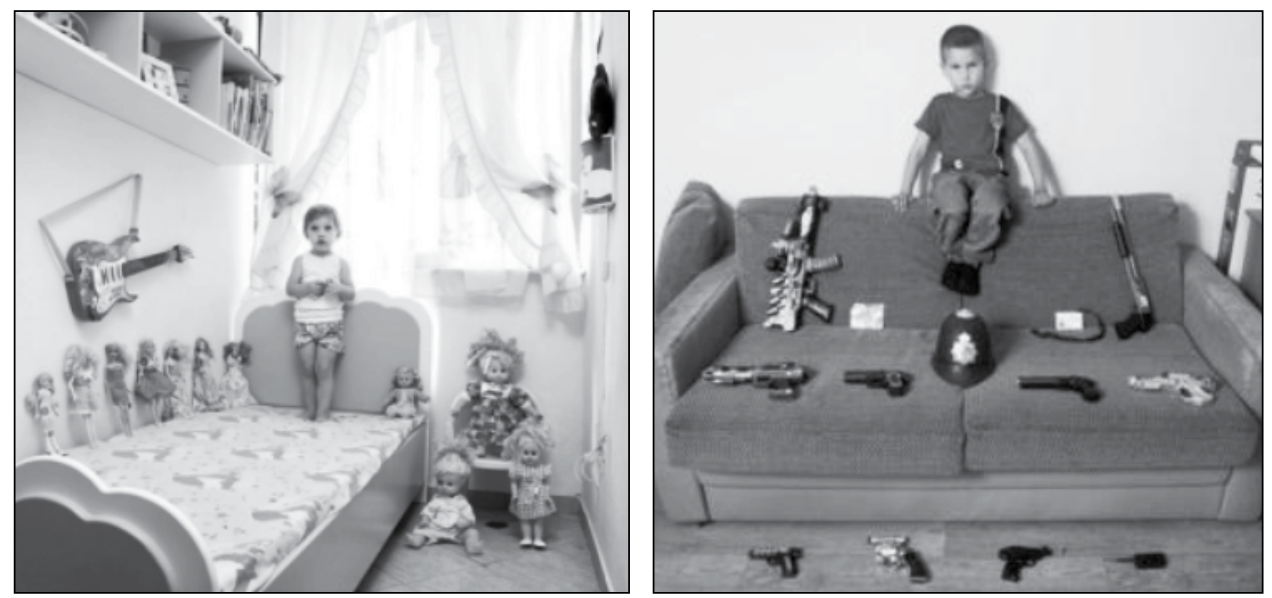

Fuente: Galimberti (2013).

Las representaciones sociales son definidas por Serge Moscovici como un corpus organizado de conocimientos y actividades que hacen inteligible la realidad física y social. En palabras sencillas, son saberes prácticos, de "sentido común" sobre la realidad que se vive (ápud Mora 2002: 7).

Por otro lado, antes de observar los spot de juguetes, hay que hacer la diferenciación entre sexo, género y roles. Forno (2011) separa estas tres categorías definiéndolas de la siguiente manera:

- Sexo es el conjunto de características genéticas, gonadales, hormonales y anatómicas que tipifican a un ser humano como hombre o mujer; está estrechamente vinculado con los cromosomas sexuales (X o Y).

- Género se refiere al sexo socialmente construido y definido a partir del sexo asignado al momento del nacimiento, es decir son las normas, valores, costumbres, características, responsabilidades, roles, que se transmiten dentro de un grupo social o sociedad para diferenciar lo masculino de lo femenino y a los individuos definidos desde esta perspectiva para formar parte de una organización social.

- Rol de género es el papel que como hombre o mujer asumimos en nuestra cultura, es decir, el comportamiento masculino y femenino expresado de acuerdo con costumbres, normas, valores de la sociedad.

Los juguetes, aparentemente, se relacionan con la realidad que observan los niños, pero también son producto de lo que los adultos le obsequian o compran. En este último caso, los padres de familia invierten en la compra de juguetes de sus hijos sea como recompensa por buenas notas en la escuela, desempeño deportivo o comportamiento mostrado a lo largo del año escolar. Diversos indicadores señalan que los niveles 
económicos han ido mejorando para muchos y con ello su poder adquisitivo. Entonces, vale preguntarse ¿Cuánto han invertido en los últimos años los consumidores en la adquisición de juguetes en el mercado de Lima, especialmente en la temporada navideña?

\subsection{Cifras del mercado de juguetes: Cuando estos se convierten en cosa seria}

"En el Perú, el mercado total de juguetes genera entre 75 y 80 millones de dólares. Durante los últimos años, este sector ha tenido una tendencia positiva acorde al crecimiento económico del país, en el año 2009, en plena crisis financiera internacional, logró un crecimiento entre el 5 y 7\%". Esas fueron las palabras del director de marketing de Mattel para Sudamérica y Centroamérica, Paulo Espinoza (Andina, 2010).

Algunos datos más actuales refieren que las importaciones de juguetes del mercado peruano ascendieron a 87 millones de dólares en el 2010, lo que representó una facturación de aproximadamente 160 millones de dólares para las empresas del sector. Según el gerente de ventas de Mattel Perú, Óscar Pacheco, se prevé un incremento de $20 \%$ en la venta de juguetes de dicha marca respecto al 2011, ofreciendo más de 2,500 productos y más de 30 marcas (Gestión, 2012).

Actualmente, además de Navidad o los cumpleaños, existen fechas como el "Día del Niño" que también llevan a los padres a comprar más juguetes. Las tiendas por departamento y los comerciantes, mayoristas y minoristas destinan parte de su oferta permanente a este rubro.

Las categorías y marcas que se ofrecen en juguetes son muy amplias. Rodrigo Aste, Gerente Comercial de Cencosud (supermercados Wong y Metro), reveló que dentro de las marcas con mayor demanda se encuentran Hasbro y Mattel, donde los juguetes favoritos para niñas son Monster High, Barbie Pop Star, Babyalive, entre otros. Mientras para los niños, los favoritos son las figuras de acción de Spiderman, Max Steel, Avengers y autos Hot Wheels (Gestión, 2012).

Los medios de comunicación también consideran importante este rubro. Sea por acuerdos con las grandes marcas auspiciadoras (el dinero invertido en publicidad de juguetes asciende a cifras altas, como se verá más adelante) o por costumbre, los programas periodísticos suelen presentar en las semanas cercanas a la Navidad informes sobre las "últimas novedades" de juguetes (figuras 10-12). En algunos casos se visita solo las grandes cadenas de tiendas por departamento, pero, dependiendo del enfoque que tenga el programa, pueden visitarse además los grandes mercados populares. No obstante, estos reportajes (emitidos desde un medio considerado "serio") proponen qué comprar, qué pedir y cuánto invertir en los regalos para los niños.

Asimismo, estos reportajes son emitidos usualmente en las mismas semanas. Por ende, no es difícil imaginar el efecto multiplicador que puede tener este tipo de mensajes tanto en los niños como en sus padres. 
Figuras 10, 11 y 12: Los programas dominicales proponen a los niños y padres qué pedir, cuánto debe ser el monto de la inversión y dónde comprar.
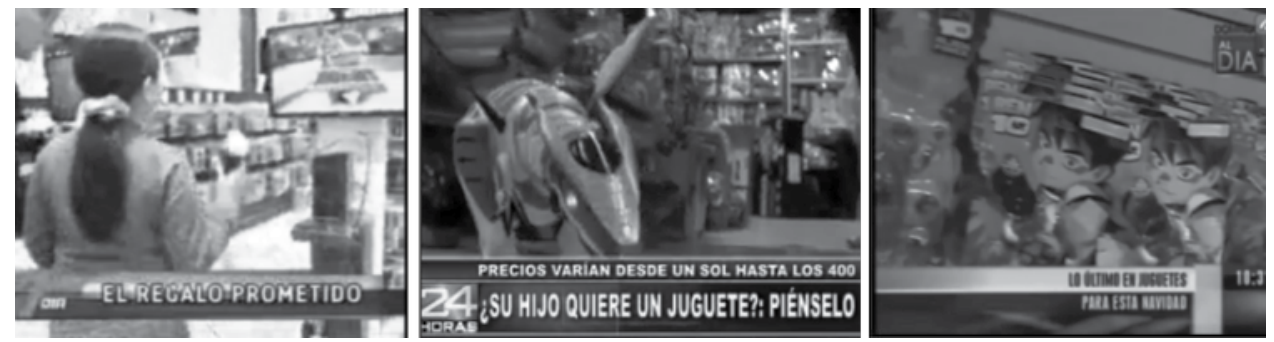

Fuente: YouTube (2012b-2012c, 2011a y 2010a).

Se observa que hay una considerable inversión proyectada en este sector. Por tanto, vale preguntarse cómo fue la inversión de publicidad en los últimos dos años para identificar las empresas más importantes, así como las marcas y programas dónde se invirtió en publicidad.

\section{3. ¿Quién, cuánto, dónde y cuándo? Balance de los spots navideños en señal abierta (2011-2012)}

Según los datos del estudio realizado por CONCORTV (2012), un 97\% de los niños encuestados observa televisión de lunes a viernes y un $95 \%$ lo hace los sábados, siendo las horas principales de consumo de 7 a 8 pm de lunes a viernes y de 8 a 9 pm los sábados. De acuerdo con el balance, los niños consumen en promedio 3 horas y 30 minutos de televisión al día. Sus programas favoritos son "Al Fondo hay Sitio", "Combate", "Esto es Guerra" y "Yo soy" (ibídem). Esto nos permite tener una idea de las características en cuanto al consumo de medios de este grupo en particular.

Para el análisis de las campañas de juguetes en Navidad se plantean ciertos criterios de búsqueda como los montos de inversión que hicieron las empresas en publicidad televisiva, número de avisos emitidos, qué compañías pagaron por los avisos, para cuáles de sus marcas se realizaron y los horarios en los que se difundieron. Para ello, se recurrirán a los datos de medición de IBOPE TIME, empresa que se dedica en Perú a medir los avisos publicitarios en televisión de señal abierta y goza de amplio reconocimiento dentro de este negocio.

La inversión publicitaria en spots de juguetes de Navidad ascendió a un total de 4’219,238 millones de dólares en el año 2011. Para el año siguiente se observa una inversión de 4'982,967.9 millones de dólares. ¿Esta diferencia corresponde a un mayor número de avisos emitidos? La respuesta es negativa.

Para el año 2011 se emitieron un total de 7,860 avisos; mientras en el año 2012, el total de avisos emitidos fue de 4,909 avisos (incluyendo repeticiones). La distribución del número de avisos por canal de televisión de señal abierta se presenta en la siguiente tabla: 
Figura 13: Cantidad de avisos durante emisiones de programas dominicales.

\begin{tabular}{|l|c|c|}
\hline CANAL DE TV (SEÑA A BIERTA) & 2011 & 2012 \\
\hline Frecuencia Latina & 890 & 631 \\
\hline América Televisión & 1456 & 1752 \\
\hline Panamericana Televisión & 20 & 0 \\
\hline ATV & 16 & 67 \\
\hline Global Televisión & 4804 & 2459 \\
\hline La Tele & 674 & 0 \\
\hline TOTAL AVISOS & $\mathbf{7 8 6 0}$ & $\mathbf{4 9 0 9}$ \\
\hline
\end{tabular}

Fuente: Elaboración propia (basada en IBOPE TIME, 2011-2012).

Frecuencia Latina y América Televisión son consideradas “antenas calientes" debido al alto rating de sus programas. Esto las convierte en plataformas muy atractivas para los anunciantes debido a la alta posibilidad de ser observados. Sin embargo, Global Televisión y La Tele no poseen programas muy sintonizados, pero el alto número de spots puede deberse, esencialmente, a que sus costos por segundo son mucho más bajos que los del primer grupo. Además, Global Televisión es uno de los pocos canales que ofrece una programación infantil (de lunes a viernes) de dibujos animados, mientras los demás canales o no la tiene o sus programas son de corte más juvenil (telenovelas, programas concursos o series), lo cual marca diferencia importante para el planificador encargado de la selección de dónde invertir.

De otro lado, si bien la inversión y el número de avisos expresan cifras distintas, quizá la mayor diferencia radique en el número de marcas que invirtieron en publicidad televisiva. En el 2011 fueron tres marcas las que invirtieron en publicidad televisiva. En el 2012 solo dos.

Las empresas que invirtieron en estos avisos para el 2011 fueron Hasbro, Mattel y Suckot. $\mathrm{Al}$ año siguiente, solamente las dos primeras continuaron invirtiendo en este medio. Para el 2011, los spots fueron emitidos de la siguiente manera: 813 avisos para la empresa Hasbro (388 en noviembre y 425 en diciembre), Mattel emitió 6,915 avisos (1,173 en octubre, 1,500 en noviembre y 4,242 en diciembre) y Suckot 132 avisos (99 avisos en noviembre y 33 avisos en diciembre). Para el 2012, Hasbro emitió 330 avisos (39 en octubre, 94 en noviembre y 197 en diciembre) y Mattel 4,579 avisos (480 en octubre, 1,067 en noviembre y 3,032 en diciembre).

Mattel es el mayor fabricante de juguetes en el mundo. Su sede de operaciones está ubicada en El Segundo (California, Estados Unidos). Dentro de los juguetes que distribuyó en Perú en las campañas 2011 y 2012 tenemos Barbie, Cars (personajes de la película de Disney), juguetes de la marca Fisher Price para los más pequeños, Little Moomy, Polly Pocket, Hot 
Wheels, Max Steel, Monster High, Uno Moo, Mickey, Batman, Disney princesas, Diario secreto, Fijit, entre otros.

En la campaña navideña para Perú en el 2011, el mayor número de spots fueron para la muñeca Barbie con 2017 avisos, seguido por los autos de carrera Hot Wheels con 1077 avisos, luego las muñecas Monster High con 632 y el muñeco Max Steel con 286. Para el 2012, las cifras son las siguientes: Barbie, 547 avisos; Hot Wheels, 1,038; y Max Steel con 1,123 avisos.

Figuras 14, 15 y 16: Barbie, Hot Wheels y Max Steel fueron los juguetes con mayor número de avisos propuestos por la marca Mattel.
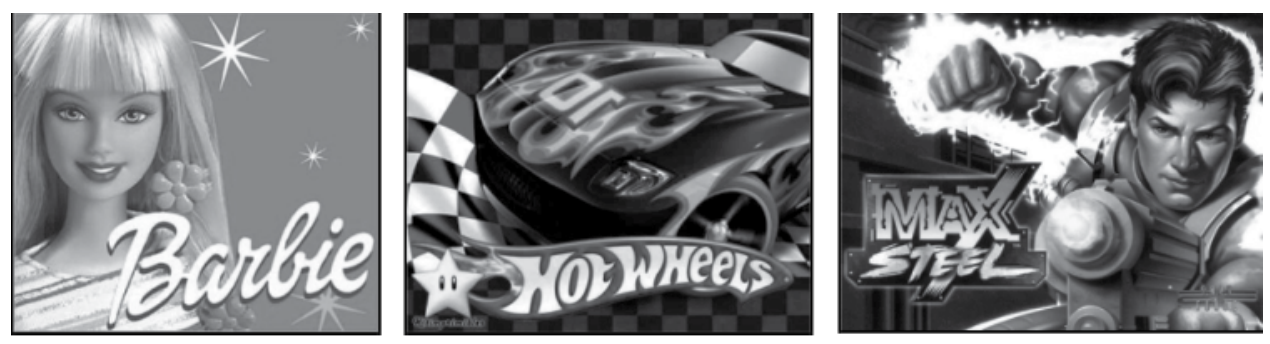

Fuente: Google imágenes (2013).

Hasbro es la segunda empresa fabricante de juguetes a nivel mundial. En el Perú, la campaña 2011-2012 tuvo los siguientes juguetes: Cuponk 20, Baby Alive, FurReal Friends, Littlest Pet Shop, Monopoly, My Little Pony, NERF, Elefun, Beyblade, KRE-O, Transformes Prime, Twister, Plaskool. El número de spots emitidos el 2011 fue 168 para NERF, 124 para LPS y 95 para el juego de mesa Monopoly. Para el año siguiente, las cifras se dividieron de la siguiente manera: Monopoly, con 64 avisos; NERF, con 50; y Littlest Pet Shop con 47.

Figuras 17, 18 y 19: Hasbro concentró su oferta en el juego de mesa Monopoly, las pistolas de dardos NERF y las mascotas de Littlest Pet Shop.
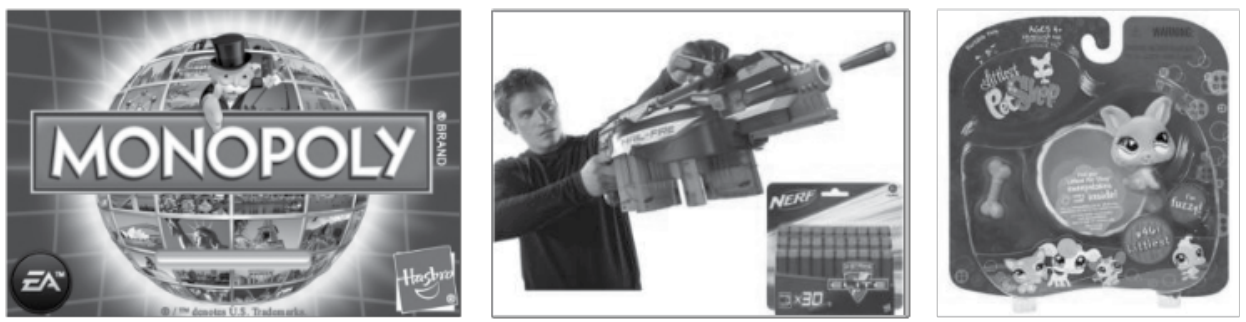

Fuente: Google imágenes (2013).

Suckot es una empresa peruana dedicada a la importación y distribución de juguetes exclusivos. Distribuyen veinte marcas reconocidas como Spiderman, Bakugan, Monsuno, 
Lalaloopsy, Hello Kitty, Techdeck, Bratz, Bratzillaz, FlickTrix, MoshiMonsters, Power Rangers Samurái, Thomas and friends, entre otros. La oferta en la campaña de Navidad se centró solo en el 2011 con la muñeca Lalaloopsy, con 132 avisos.

Figuras 20, 21 y 22: Suckot distribuye juguetes reconocidos, como las muñecas Bratz o Spiderman, aunque su oferta se centró en la muñeca Lalaloopsy.
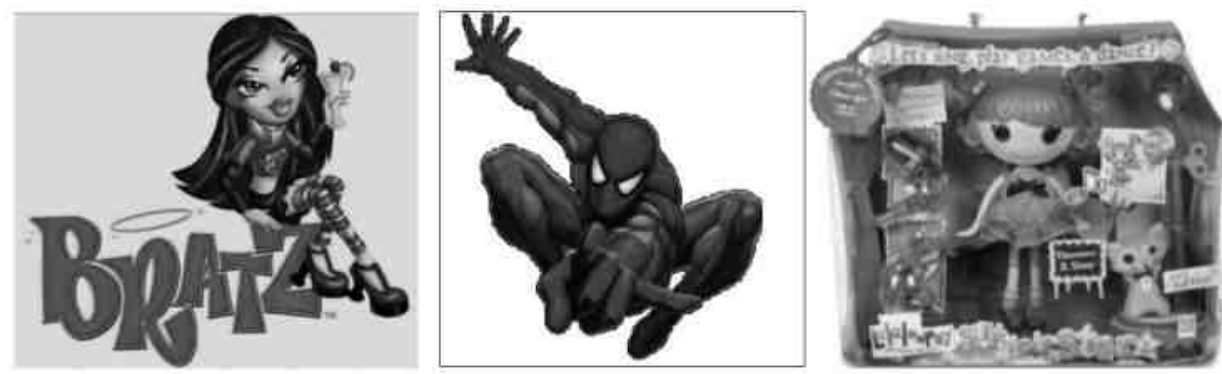

Fuente: Google imágenes (2013).

Finalmente, los spots que analizaremos serán de las tres marcas, principalmente de aquellos que alcanzaron las cifras más altas. Barbie, Hot Wheels y Max Steel, en el caso de Mattel; Monopoly, NERF y Littlest Pet Shop, para Hasbro; y Lalaloopsy para Suckot. No obstante, también incluiremos algunos otros spots que ayuden en la descripción de las representaciones de género.

\subsection{Abriendo la caja de Pandora: Propuesta dicotómica}

El juguete puede ser apreciado no solo por las horas de entretenimiento que brinda al niño. En algunos casos podría observarse otras características como si se trata de un juguete original o de una copia, el tipo de accesorios con los que cuenta, lo que hace, su costo, qué tan pronto ha sido adquirido desde que se ha emitido la campaña de publicidad, etc. De este modo, permite establecer distinciones o diferencias que logran identificar a un grupo de otro y contribuyen al capital adquirido por los sujetos (Bordieu, 1988).

Asimismo, los juguetes son llevados por los niños(as) a diversos espacios o campos (usando la terminología de Bordieu) como pueden ser la casa, la escuela o la calle. En estos espacios, la lógica social sigue su curso: se esperan comportamientos para el niño y la niña, los cuales son reforzados por aquellos productos que consumen y los evidencian (distinguen) como pertenecientes a un determinado grupo (sea por género, etnia, nivel socioeconómico, etc.) todo ello engarzado desde un conjunto de saberes prácticos.

Muchos de estos "saberes prácticos" descansan sobre una serie de signos e ideas que establecen roles en el comportamiento de las persona. Bordieu (1988: 182-183) llama a estas ideas y constructos habitus los cuales "le dan lógica y sentido" a nuestra forma de vida, es más, establecen nuestro estilo de vida. Para el autor, existen tres categorías para "distinguirse" unos de otros: alimentación (incluidas comidas en restaurantes o bebidas 
en cantinas), cultura (libros, periódico, discos, deportes, juguetes, música y espectáculos) y gastos de presentación de uno mismo (vestido, calzado, limpieza, artículos de tocador, empleados del hogar), lo cual varía según los grupos de personas.

De este modo, observamos que los juguetes también forman parte del componente social, del estilo de vida de la persona, el cual es determinado de antemano por la sociedad al haber asignado ciertos patrones de consumo que son repetidos por los niños que los observan en la publicidad, en casa, la escuela o la calle.

Para el análisis de los spots partimos primero de separar los motivos (spots únicos) de las repeticiones $^{2}$. En algunos casos también han repetido el mismo producto al año siguiente.

Figura 23: Motivos de spots publicitarios de juguetes durante las campañas navideñas.

\begin{tabular}{|c|c|c|c|}
\hline MARCA & PRODUCTO & 2011 & 2012 \\
\hline \multirow{3}{*}{ Mattel } & Barbie & 12 & 16 \\
\hline & Hot Wheels & 7 & 18 \\
\hline & Max Steel & 3 & 10 \\
\hline \multirow{3}{*}{ Hasbro } & Monopoly & 1 & 2 \\
\hline & NERF & 4 & 2 \\
\hline & LPS & 2 & 2 \\
\hline Suckot & Lalaloopsy & 1 & 0 \\
\hline
\end{tabular}

Fuente: Elaboración propia (basada en IBOPE TIME, 2011-2012).

El trabajo de Ferrer (2007), sobre juguetes realizado en la ciudad de Madrid, nos da una pauta para empezar nuestro análisis. Se examinan los juguetes desde la presentación del producto, el grado de realismo, explotación de la credulidad del niño y/o experiencia de los niños, presentación real de los juguetes anunciados, violencia y estereotipos de género. Tomaremos algunas de las categorías, pero primará especialmente la última.

Los spots $^{3}$ muestran diversos elementos en las representaciones de las actividades que deben realizar los niños, con qué objetos (juguetes) y en dónde. Lo primero que se

\footnotetext{
2 Esto es definido por la codificación que aparece en la hoja de trabajo de IBOPE. Se asume que la codificación es única cuando el spot hace alusión a un producto diferente dentro de la marca.

$3 \mathrm{Si}$ bien se ha tratado de acceder a todos los spots de los productos seleccionados en el lapso de tiempo definido, ello no ha sido posible. Por tal motivo, se ha recurrido a la red gratuita de videos YouTube. Sin embargo, tampoco se ha logrado encontrar a todos. A pesar de esto, consideramos que el número de spots hallado (31 en total) permitirá cumplir con los objetivos planteados al inicio de la investigación.
} 
observa es que la oferta de juguetes, mayoritariamente, ofrecen a las niñas muñecas y mascotas (Barbie, Littlest Pet Shop y Lalaloopsy); mientras que a los niños, muñecos, autos y pistolas (Max Steel, Hot Wheels y NERF). Como refiere Díaz (2011) la oferta de juguetes, hasta hoy en día, suele proponer a las niñas juguetes relacionados con la maternidad, las tareas domésticas, la belleza, la fragilidad; mientras que para los niños los juguetes están orientados a propiciar destrezas físicas, la fuerza, la astucia y el poder.

Figuras 24 y 25: Las muñecas tipo Barbie y los muñecos de acción tipo Max Steel suelen condensar la oferta de juguetes en Lima.
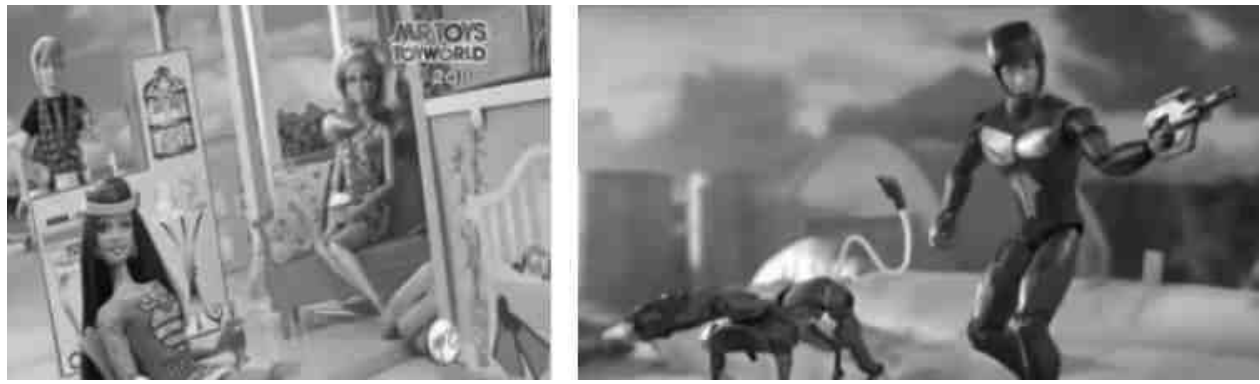

Fuente: YouTube (2012e y 2013a).

En segundo lugar, las representaciones propuestas muestran la separación de los actores (niños y niñas). "Los niños no juegan con las niñas", rezaba un viejo refrán. Y los spots perpetúan, de manera general, esta mirada.

Figuras 26 y 27: Los spots de muñecas y mascotas siguen mostrando solo a niñas, mientras que los de muñecos, autos o armas muestran solo a ellos.
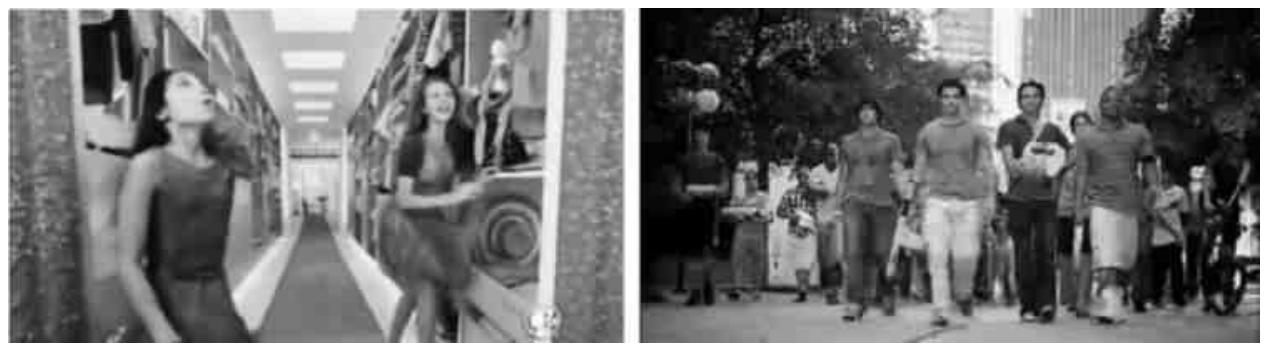

Fuente: YouTube (2012h y 2011i).

El único spot que en principio muestra a niños y niñas fue Monopoly Millonario (figura 28). Sin embargo, si bien exhibe a adolescentes de ambos sexos, las actividades que realizan convertidos en millonarios (propósito del juego) recaen en los estereotipos clásicos y los separan nuevamente. Ella, con dinero, buscará comprar joyas; él, pasarla con los amigos. 
Figura 28: Monopoly muestra a adolescentes juntos, replicando los estereotipos asignados para sus comportamientos sociales.
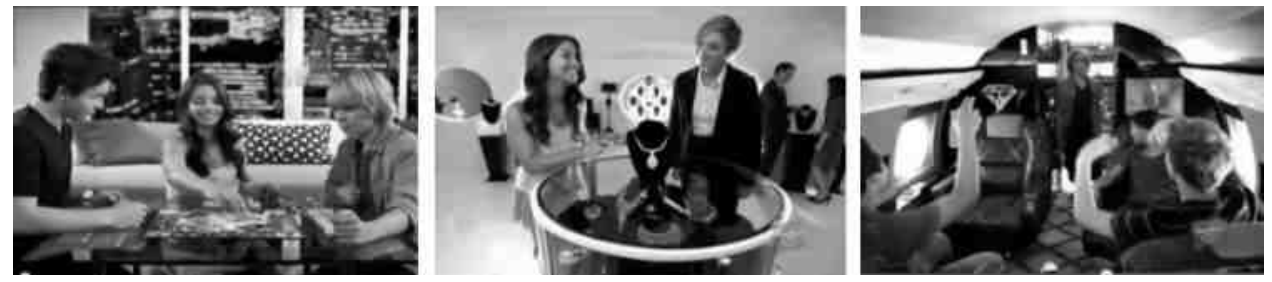

Fuente: YouTube (2012u).

Un tercer punto de análisis es el referido a los accesorios que ofrecen estos productos. En el caso de las muñecas tipo Barbie, Lalaloopsy o las mascotas de Littlest Pet Shop suelen ser accesorios referidos a moda, casa, playa, cocina, crianza de la mascota, belleza, rol de madre. De otro lado, los accesorios en los juguetes de niños ofrecen rampas, animales feroces, armas y vehículos de combate.

Figuras 29 y 30: Los accesorios también pueden incidir y en la selección de los juguetes y reforzar roles.
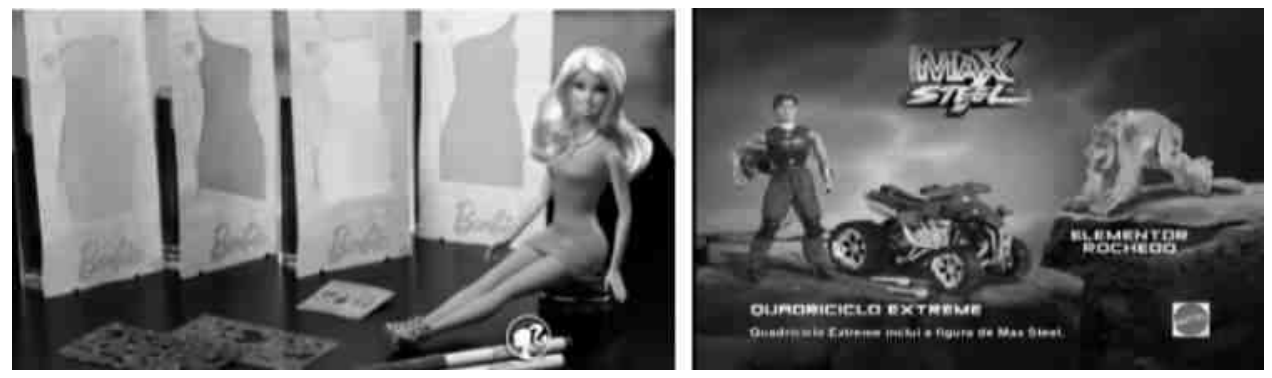

Fuentes: YouTube (2012i y 2012p).

Es interesante también hacer hincapié en la forma cómo acciones similares son ofrecidas a niños y niñas. Por ejemplo mientras que a ellas se les ofrece la posibilidad de diseñar los vestidos de sus muñecas (figura 29) o cambiarles el peinado, vale decir, pintarles el cabello (figura 31), a ellos se les dice que "transformarán sus autos con moderna luz y pintura radical". En términos simples, pintarán sus autos (figura 32): 
Figuras 31 y 32: Los spots de muñecas y mascotas siguen mostrando solo a niñas, mientras que los de muñecos, autos o armas los muestran solo a ellos.
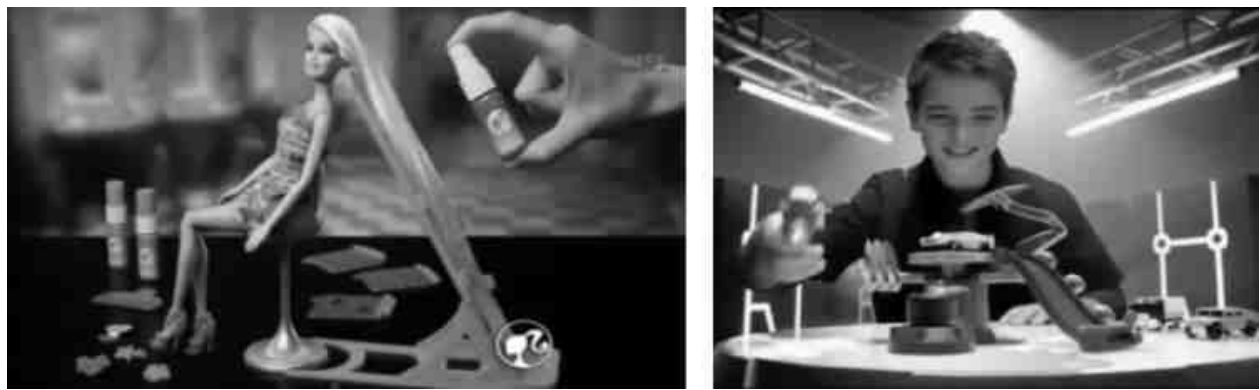

Fuente: YouTube (2012k y 2012n).

Esto nos lleva a mirar los espacios donde se propone el uso de los juguetes. Las propuestas para ellas suelen mostrar espacios reducidos o interiores. Si bien los espacios son distintos entre sí, apuntan a lugares (y actividades) que se desarrollan dentro de casa o una habitación (figura 33) como un salón de belleza, una sala de diseño de ropa, jugar a ser mamá, enfermera, veterinaria, maestra, chef, etc. En efecto se pueden observar algunas excepciones, pero son pocas ${ }^{4}$. En cambio, las propuestas para ellos están unidas a grandes espacios al aire libre como parques donde desarrollan sus combates, pistas de carreras, la ciudad entera (figura 34) o escenarios naturales (mar, montaña, selva, volcanes, cavernas, desiertos) donde tienen lugar las aventuras de sus personajes, estableciendo una figura donde ellos tienen y deben estar en el espacio público (o conquistarlo) y ellas están más asignadas al espacio privado.

Como refiere Nieto (2003), mientras ActionMan (“el héroe más grande de todos los tiempos") lucha en las calles contra el Doctor X, Barbie lava a su perrito o prepara pastelitos y gelatina en su "cocina mágica". Estamos ante un mundo bipolar cuyos límites, para ellas, se quedan entre los muros del hogar, y, para ellos... inalcanzables, porque el universo lúdico de los varones es un auténtico macrocosmos donde abundan los mundos fantásticos.

4 El producto que más ha trabajado el tema de las profesiones es la muñeca Barbie, pero las demás muñecas suelen mantenerse en los roles de ama de casa. 
Figuras 33 y 34: Ellas tienen escenarios cerrados, mientras que para ellos el mundo es su patio de juegos.
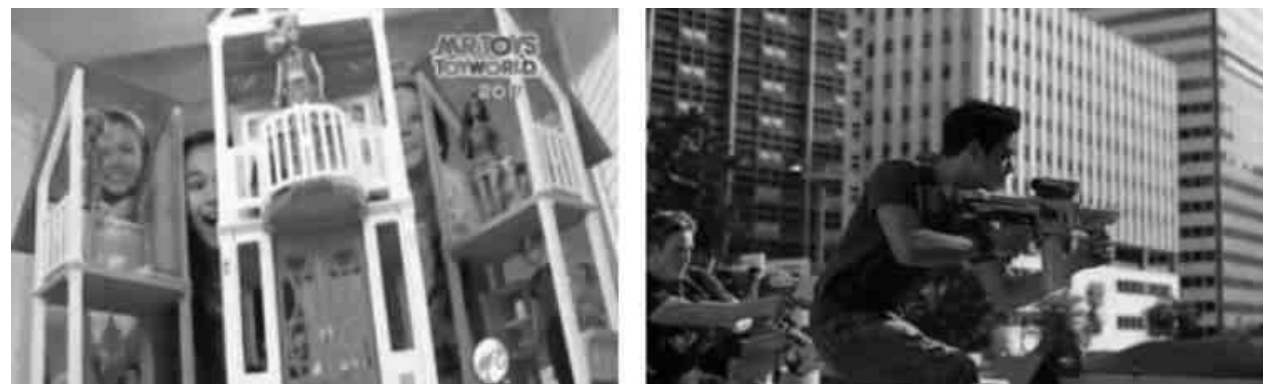

Fuente: YouTube (2012e y y 2011i).

Este punto lleva a mirar algunos de los elementos propuestos en el análisis de Ferrer (2007: 139-140), referidos al grado de realismo de la publicidad en los juguetes y su manipulación. Los escenarios en la publicidad son creados por computadora o mezclan la realidad donde insertan al juguete (y proponen al niño donde debería jugar). En algunos casos, los juguetes tienen una versión animada de ellos o son movidos por una mano, sea de manera evidente o muy rápida (figura 37). Si bien aparece la advertencia, lo cual lo exime de ilícitos legales, es evidente el propósito de hacer que el niño o la niña piense que su juguete hará lo mismo que hace en el spot en televisión.

Lo más importante es que al presentar una versión animada de sí mismo, propone al niño o niña una mirada de un yo futuro. Barbie no aparece como niña, sino como adulta (o adolescente). Max Steel sigue la misma lógica, mientras Hot Wheels presenta las acrobacias del "Equipo Hot Wheel" con pilotos reales (figura 35) que realizan acrobacias verdaderas en vehículos similares a los que promociona.

En cambio, NERF no utiliza modelos semejantes a su público objetivo: muestra a adolescentes que muy probablemente no usen nunca ese producto, pero puede llevar al niño a pensar que si esa persona lo usa, él también puede hacerlo. Algo similar sucede con mucha de la publicidad donde Barbie interactúa con personas reales (figura 36). Puede pensarse que no necesariamente corresponden al grado etario propuesto más aún cuando actualmente los niños abandonan los juguetes con una mayor velocidad debido a la propuesta de consumo "más adulta" que le propone la sociedad. Tomemos en consideración el set para el cabello de Barbie (figura 31): una adolescente iría a un salón de belleza, en cambio, una niña más pequeña probablemente no, pero al mirar a la adolescente es muy posible que crea que ella usa el mencionado juguete y por imitación lo pida. 
Figuras 35, 36 y 37: Mostrar personas reales, proponer una versión digital o interactuar con el juguete son algunos recursos que se usan en la publicidad.

Sin embargo, lo importante es el "yo futuro" que algunas marcas proponen.
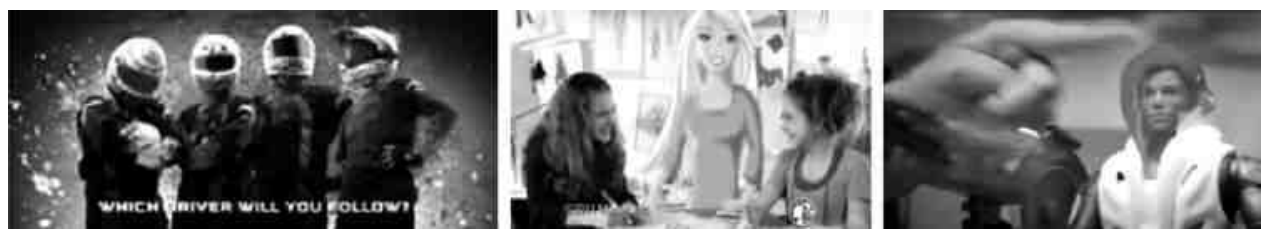

Fuente: Youtube (2011f, 2012i y 2012q).

Un tema aparte son las representaciones que propone la muñeca Barbie. Este producto, con el tiempo, ha cambiado el discurso. Por ejemplo, el spot "Barbie when I grow" (figura 38) muestra cómo las mujeres "pueden ser lo que sea"; y se aprecia a mujeres siendo pilotos, bomberos, deportistas y artistas. Profesionalmente pueden ser lo que quieran, pero ¿qué representaciones hay sobre la belleza? En cuanto a este tema, la muñeca sigue promoviendo una belleza irreal en muchas niñas: más alta que el promedio, con una cintura muy delgada, con busto y caderas pronunciadas. Una muñeca más real sería más baja, más ancha de cintura e incluso con algo de panza (figura 39). Sin embargo, este ideal estilizado puede llevar incluso a que mujeres y hombres se sometan a operaciones para ser "perfectos" (figura 40):

Figuras 38, 39 y 40: Barbie sigue promoviendo cánones de belleza utópicos.
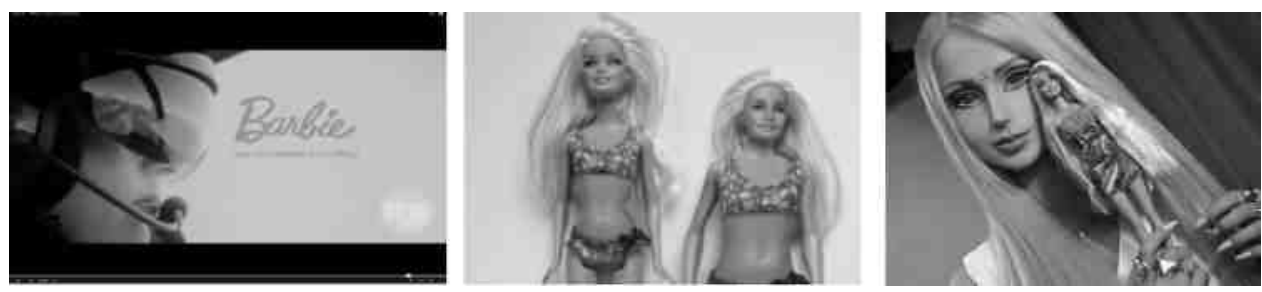

Fuentes: Youtube (2011m), La Razón (2013) y Noticias 24 (2013).

Esto podría tener consecuencias respecto a la construcción que muchas niñas pueden hacer de ellas mismas al tener un juguete que les remita a una belleza que no poseen y que es valorada; por ende, es muy probable que intenten poseerla, sea por ejercicios $u$ operaciones de cirugía estética o llevarlas a un sentimiento de inferioridad que puede terminar en desórdenes alimenticios como la anorexia y/o bulimia, con desenlaces fatales en algunos casos. Además de ello, propone una imagen consumista para las niñas con una serie de accesorios en donde lo importante es tener "todo el set completo". Situación que nunca sucederá pues la marca se encarga de sacar un nuevo set, producto o accesorio con mucha frecuencia. Quizá esto sea una de las razones por las cuales algunos padres y organizaciones diversas protestan contra la muñeca más famosa del mundo. 
"Cuando la muñeca no está en la cocina, aparece convertida en todo un objeto sexual. Así, las Bratz (figura 20), con los labios y ojos pintados y 'tan atrevidas como tú, prometen a sus compradoras brillar 'en la pista y por la noche'. Eso sí: como buen objeto, la niña-mujer persiste en su ancestral actitud pasiva" (Nieto, 2003). Esta representación sigue en debate y ocasiona protestas de padres y de distintos movimientos ciudadanos por los estereotipos que la muñeca fomenta (El Comercio, 2013).

Si trasladamos las representaciones que van creando los niños y niñas diríamos que ellos son "luchadores y "conquistadores" y ellas "delicadas princesas". ¿Qué representaciones de ellos mismos tendrán en las siguientes etapas de sus vidas?

Al respecto, Yon (1998: 26-29) ha desarrollado un trabajo en cinco barrios de Lima dirigido a adolescentes de distintos sexos acerca de las percepciones de ellos mismos y del otro(a). Las jóvenes consideran que la mujer ideal debe tener cinco aspectos básicos: sinceras y fieles; comprensivas y cariñosas; tranquilas y respetables; inteligentes y tener ganas de progresar. En el caso de los hombres, ellos idealizan a la mujer perfecta como bonita y de buen cuerpo. Esas son sus características básicas, luego mencionan que debe ser cariñosa y comprensiva; respetable y de "su casa"; ser buena esposa y madre.

Cuando la autora consulta sobre el hombre ideal, las mujeres lo definen en cuatro aspectos: cariñoso, con buenos sentimientos, comprensivo; guapo, atractivo; respetuoso y fiel; que estudie/trabaje. Cuando se hace la pregunta a los hombres, en principio hay una actitud de rechazo y defensa: "soy como soy, no tengo de que avergonzarme", pero luego mencionan que debe ser cariñoso, comprensivo con su pareja; inteligente; guapo y fuerte (ibidem: 30-31).

Sincera, fieles, tranquilas; atractivo, respetuoso, fiel... Estas representaciones podrían asemejarse mucho a las representaciones de los príncipes y princesas de los cuentos de hadas y de los juguetes que se promocionan en la infancia. ¿La vida suele ser así, siempre con finales felices y sin problemas?

Figura 41: Embarazos no deseados, cáncer o cirugías plásticas (para mantener la belleza) son algunos de los tópicos que aborda la artista

Dina Goldstein al retratar a las princesas Disney en el mundo de hoy.
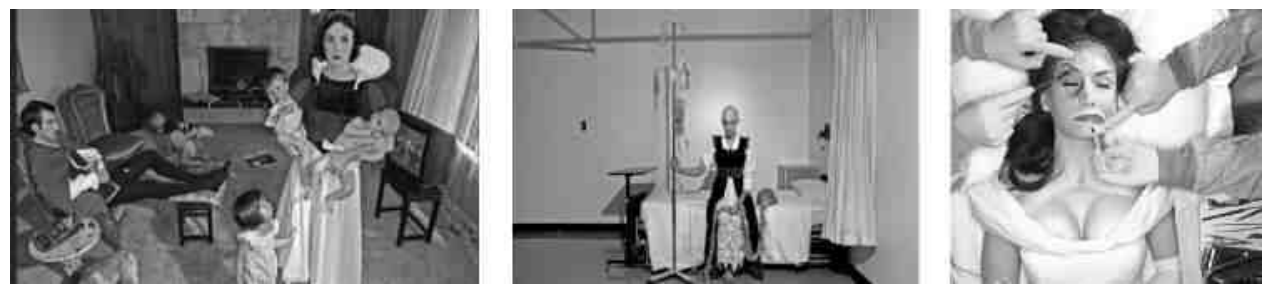

Fuentes: $B B C(2013)$. 
Existe una construcción muy marcada sobre los valores que debe tener el hombre y la mujer, así como los roles que debe asumir cada uno. El modelo ideal masculino suele ser agresivo (e incluso abusivo), diestro en deportes, descuida sus estudios y desafía la autoridad (Callirgos, 1998: 50). Respecto a las emociones, se suelen suprimir ("los hombres no lloran") y si esto sucede, esa persona es considerada débil y, por tanto, "merece" ser castigada (bullying). La mujer muchas veces es unida a todo lo contrario ("necesita ser protegida"), debe ser sumisa, frágil, estudiosa, respetuosa, "de su casa”, etc.

Es importante reflexionar sobre ello, porque el varón crea su sexualidad en oposición, es decir, deberá convencer que no es una mujer, ni un bebé, ni un homosexual (Badinter, 1994: 62). Mira de manera inferior o despectiva al otro (u otra). Esta polarización hace que hombres y mujeres se observen, en muchas ocasiones, como seres que solo pueden navegar en uno u otro polo. En el caso de la mujer, especialmente, esta es encasillada como virginal y pura o una mujer manipuladora, malvada, que usa la sexualidad para lograr sus propósitos 5 .

Las cualidades y atributos que desarrollan los juguetes se identifican con lo que "se espera" que sea una mujer o un hombre (Alonso, 2008). Los medios (incluyendo la publicidad) pueden influir en la forma cómo los niños(as) construyen su percepción del mundo, su sistema para obtener recompensas y aceptación, se hace dentro del sistema, rara vez fuera de él (Ministerio de la Igualdad, 2009). Sin embargo, ¿los niños aceptan sin cuestionamientos estas representaciones? ¿Qué sucede si algún niño quiere jugar con una muñeca o una niña con un carrito o una pistola?

\subsection{Ni princesas ni superhéroes. Niños en pie de lucha}

Según Fuller (2001: 130), los juegos masculinos (fútbol, policías y ladrones, etc.) son los más valorados, de ahí los mixtos (papá y mamá, doctor y enfermera, etc.) y finalmente los femeninos (casita, muñecas, etc.) que deben ser evitados. ¿Esta misma lógica pueda aplicarse a los juguetes? ¿Existe una división de juguetes para niños y niñas?

Ya hemos visto que sí. Conscientemente o no, la industria de juguetes separa claramente aquello que es para niños y lo que es para niñas. Catálogos, espacios en las jugueterías, spots publicitarios revelan uso de colores, actores, modos, que mantienen la separación de niños y niñas porque les permite claridad en el mensaje y enfocar al otro público al cual se dirigen: los padres de familia. Ellos son quienes comprarán los juguetes desde su propia construcción de género, designación de roles que asigna a uno y la valoración que hace de los mismos. Por ello, es muy común ver a padres "preocupados" cuando su hijo juega con muñecas o su hija lo hace con carritos.

5 Al respecto, Alfaro (2006) expone los estereotipos de diversas series y telenovelas nacionales. Los postulados que presenta siguen teniendo vigencia porque la esencia de los mismos no ha cambiado en lo absoluto. 
Cuando se presenta esta situación, genera mucha confusión en los padres sobre la orientación de género de su hijo(a). Un niño que quiera jugar con muñecas o vestirse de princesa, una niña que prefiera los muñecos con armas... muchos padres terminan preocupados porque extrapolan una situación que puede ser motivada por la curiosidad, un momento pasajero y crean culpas, miedos y vergüenza en niños y niñas. La mirada clínica indica que hay muchos factores a tomar en cuenta antes de suponer que el niño o niña posee una orientación diferente a su sexo ${ }^{6}$ (Fundación Eduardo Punset, 2012). Sin embargo, la mayor intolerancia y fuente de los miedos proviene de la sociedad que margina, persigue, castiga y ridiculiza lo diferente. Los casos de bullying escolar y de suicidios de niños (especialmente) por vivir su orientación sexual (o incluso ser asignados a una) dejan entrever que hay mucho que combatir respecto a este tema desde muy pequeños. Dicha educación debe ir tanto a padres, alumnos, maestros y personal administrativo.

Figuras 42 y 43: El temor suele estar en los padres y en cómo sus hijos pueden ser estigmatizados $\mathrm{y}$ acosados por desarrollar patrones distintos a los esperados.
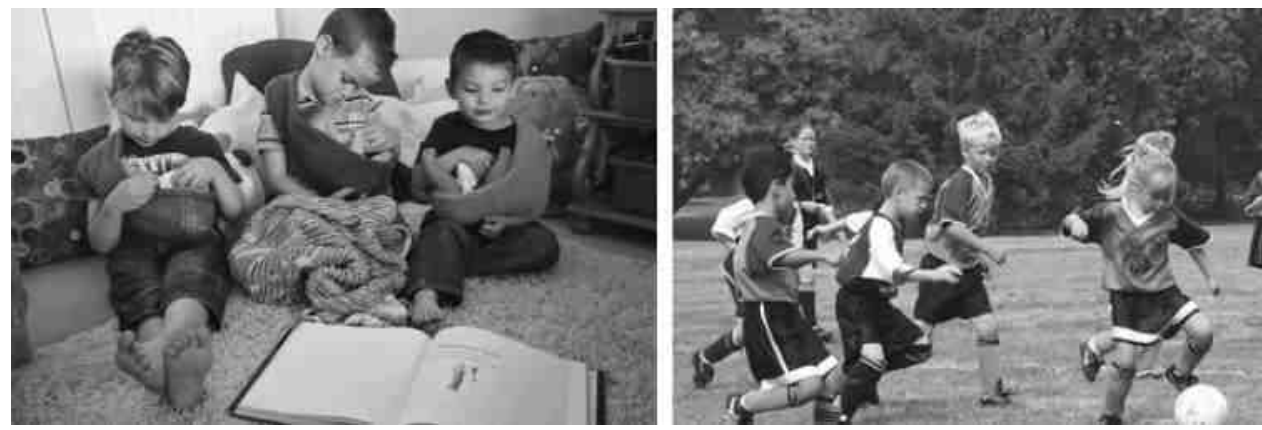

Fuente: Google imágenes (2013).

Si bien para algunos los juegos son para quien los juega y su magia está en disfrutarlos con toda la libertad sin pensar que son de niñas o de niños (Ministerio de la Igualdad, 2009), en más de una ocasión he tenido la oportunidad de ver niños que juegan con muñecas, las visten y se preguntan ¿qué le ven de divertido? Muchas niñas también disfrutan de los juegos de niños. Les parecen atractivos los accesorios y los diseños. Sin embargo, ¿qué sucede cuando un niño quiere jugar con muñecas o prefiere vestirse de color rosa? ¿Qué pasa cuando una niña no quiere las muñecas y prefiere un balón de fútbol o una pistola?

6 Siguiendo los criterios del DSM IV, el trastorno de identidad sexual en los niños se manifiesta de las siguientes formas: a) deseos repetidos de ser o insistencia en que uno es del otro sexo; $b$ ) en los niños, preferencia por el transvestismo o por simular vestimenta femenina; en las niñas, insistencia en llevar puesta solamente ropa masculina; c) preferencias marcadas y persistentes por el papel del otro sexo o fantasías referentes a pertenecer al otro sexo; d) deseo intenso de participar en los juegos y en los pasatiempos propios del otro sexo; y e) preferencia marcada por compañeros del otro sexo. 
Toda conducta humana manifiesta el efecto de determinismos sociales que subordinan actos individuales a situaciones colectivas (Touraine, 1969: 31). Son los actores sociales los que confieren el sentido a los actos y no el sistema de la cultura o el sistema social, entendiendo por "sentido" lo que refieren Weber y Parsons: la relación entre las representaciones subjetivas de los objetos físicos, sociales y culturales y el sujeto mismo (ápud Pizarro, 1979: 45).

Los sujetos no somos pasivos. Puede que el sistema sea muy fuerte, pero, incluso desde edades tempranas, se cuestiona y, más aún, se actúa para ir en contra de lo que está establecido. Una niña puede querer jugar con carros de carrera porque quiere o le gustan simplemente; un niño podría sentirse atraído por las muñecas, los detalles de los accesorios, sin que ello derive en ningún tema dudas o cambio en la orientación sexual. Por ejemplo, Riley (una niña de 6 años) protesta en una tienda de juguetes. Su enojo está verbalizado en la siguiente frase: "No es justo que las niñas compren princesas y los niños superhéroes" (figura 44). Luego se pregunta: “¿Por qué no puede ser al revés?”. La cadena de juguetes más grande de Suecia (Top Toy) publicó un catálogo de juguetes "neutral” (figura 45).

Figuras 44 y 45: Riley protestando por las opciones limitadas de los juguetes y Top Toy promoviendo un catálogo que se aleja de los clásicos referentes.
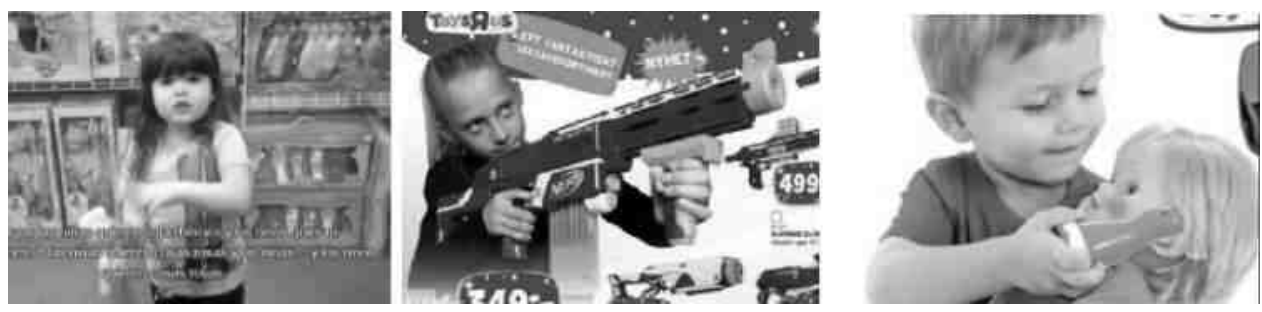

Fuentes: YouTube (2012a) y Publimetro Chile (2012).

Estas propuestas y modos de pensar son pocos. Si bien es cierto que cada vez hay más padres que tratan de tener mayor apertura respecto a la valoración de estos temas y hay "mayores" capacitaciones para docentes y escuelas para padres, pocos niños y niñas aceptan el rechazo por su decisión y optan por encajar, seguir las modas, pedir lo que aparece en las imágenes de publicidad, usar los colores, ambientar el dormitorio, vestir y jugar cómo lo indica la pantalla. Más aún cuando se cuenta con un sistema de educación que valora poco la independencia, la capacidad crítica y la autoconfianza.

Por ejemplo, cuando a un niño lo llaman "nena" o a una niña le dicen "machona" tanto padres como educadores se deben preocupar por el valor que tiene este insulto para él o ella: "Esta burla no tendrá tanta repercusión en un niño que observa que sus modelos referenciales, personas que admira (padre, hermano, un amigo, su profesor) realizan con gusto y satisfacción aquellas actividades por las que a él le llaman nena" (Paideia Libre, 2003). Sin embargo, es ahí donde radica la fuente principal del problema. Muchas veces los padres y maestros incentivan y premian a los niños que muestran las conductas esperadas. En el seminario "Publicidad y género. ¿De dónde partimos y a dónde vamos?” (Mendoza, 
2012) se presentaron diversos casos donde la publicidad propone nuevos modelos de comportamiento para hombres y mujeres: Mujeres más independientes, hombre menos machistas y más propensos a expresar sus emociones y vivir su paternidad alejado del rol de proveedor. Sin embargo, seguir proponiendo estas miradas tan excluyentes, desde los juguetes perpetúa estos modelos que seguirán siendo interiorizados, vividos, compartidos y defendidos en las siguientes generaciones. Finalmente, los juguetes no solo se compran para hoy; quizá sean comprados para establecer quienes seremos mañana (Paideia Libre, 2003).

\section{Conclusiones}

- Alfaro (2003 y 2006) considera que los medios de comunicación, las series, telenovelas y publicidad peruanas transmiten patrones de comportamiento, estereotipos que establecen nuestra construcción del yo y del otro que es evidenciado en niños, niñas y adolescentes. No obstante, ellos y ellas también cuestionan estos modelos que les parecen malos, carentes de valor y lejanos a ellos. Sería importante profundizar esta lógica y si se aplica a los juguetes. Por el momento, se puede intuir que ellos también critican el hecho de jugar solo con juguetes de "hombre" y "mujer" como en el caso de Riley (YouTube, 2012a) y que algunas cadenas (como Top Toy) han hecho eco de esta situación (Publimetro Chile, 2012). Sin embargo, el mercado peruano aún está lejos de estas situaciones, especialmente porque los adultos siguen perpetuando modelos dicotómicos que discriminan al niño que quiere jugar de manera distinta a la establecida.

- Díaz (2011) refiere que la actitud en niños y adultos sobre los estereotipos de género en juguetes infantiles indica que estos son un reflejo del mundo adulto. Sin embargo, estos objetos lúdicos no se corresponden con los ideales de igualdad de la sociedad actual. Hay campañas publicitarias que hacen eco de una nueva manera de mirar a adolescentes y adultos de distinto género. No obstante, si los juguetes siguen mostrando los mismos estereotipos estos se asentarán en los niños y niñas, serán retransmitidos, perpetuados y los que traten de ir contra el sistema serán juzgados y, probablemente, recibirán algún tipo de sanción. Los juguetes de hoy no responden a los nuevos paradigmas.

- El juguete es una interpretación que hacen los niños del mundo adulto. En el campo de género, se observa la rigidez que existe: niños "conquistadores" y niñas "sumisas". Además, se puede observar una represión y trastoque de la vida sexual al proponer juguetes asexuados para niños y niñas. "Los juguetes deberían poseer órganos sexuales externos pélvicos perfectamente delineados, pues la ausencia de ello anula nuestras características sexuales, contribuye a la ignorancia y a la negación de los cuerpos. ¿Cómo estar al tanto de cuidarse la vagina o el cuello uterino si estas partes no aparecen?” (Díaz, 2011).

- Distintos psicólogos hacen referencia al rol de los padres en la elección de los juguetes. Los niños aprenden lo que les enseñan y a veces recogen los prototipos sexistas del pasado, no por la publicidad, sino por sus progenitores (AHIGE, 2013). La elección, uso y valoración que se hace del juguete está impregnada de las interpretaciones adultas. Muchas veces un niño puede jugar con una muñeca por curiosidad y el adulto (que sigue 
concibiendo al mundo desde sus estereotipos) considera estos actos como alertas sobre si el niño se volverá homosexual o lesbiana, qué le dirá la familia, en la escuela, en la calle. En muchos casos, su preocupación radica en cómo será visto y evaluado como padre o madre.

- Sala Sivera apunta que la publicidad sí tiende a "reforzar la diferenciación y los estereotipos", aunque la intención en los últimos años es cambiar esa tendencia. "Quitar los colores identificativos sería un buen paso para generar más igualdad" (ápud AHIGE, 2013). No obstante, solo una empresa arriesgada, capaz de superar los prejuicios y los estereotipos, podría vencer este escollo. ¿Cómo? Con responsabilidad social y pensando primero en el niño, en qué le divierte y no, como se hace ahora, en el margen comercial y en convencer al padre (Nieto, 2003). Ya se observó que es posible plantear una nueva forma de presentar los juguetes (Publimetro Chile, 2012), donde los niños son alejados de los estereotipos y podrán elegir qué los divierte.

- La Navidad es un negocio. Por ello, resulta necesario reflexionar detenidamente acerca de las representaciones que emiten los juguetes respecto a los roles de género. Al ser un negocio, los anunciantes buscarán los mejores horarios para emitir el spot de televisión, usarán recursos audiovisuales que aseguren la mirada de los niños y niñas, sugerirán a través de argumentos o imágenes la compra. El spot será usado en distintos espacios o campos como la casa o la escuela (especialmente) y se mantendrán (muy probablemente) los roles que imponen los adultos, perpetuando el conjunto de ideas y estilo de vida (habitus) donde el niño y la niña, con comportamientos distintos, será excluido.

- Se suele mirar de manera "ingenua" los mensajes que se construyen de los juguetes. Ya se observó que los spots poseen una serie de cargas y valoraciones que hace el adulto de la sociedad y se las transmite al niño. Además, los reportajes "serios" contribuyen a ello a través de un lenguaje donde se verbaliza cómo deben ser los niños y qué deben realizar los padres. Atrás quedaron los carritos y los trompos (se debe primar el nuevo juguete o el juguete moderno). La felicidad no tiene precio, aunque en verdad sí, pues los juguetes la tienen y los reportajes mencionan a cuánto asciende (desde un sol hasta más de 2000 soles). Se usa un lenguaje para ellas y otro para ellos ("tiernas" versus "pícaros/ atrevidos"): "Con esta muñeca su engreída empezará a tener responsabilidades pues le enseñará cómo ir al baño y cómo asearse" (YouTube, 2012b, 2012c, 2011a y 2010a).

\section{Fuentes consultadas}

AHIGE (2013, julio 24). “¿Hay sexismo en la publicidad de juguetes?”. Extraída el 22/ VIII/2013 desde http://www.hombresigualitarios.ahige.org/index.php?option=com_content\& view=article $\& \mathrm{id}=1225$ :ihay-sexismo-en-la-publicidad-de-juguetes \& catid=36:articulos \&Itemid $=56$

Alfaro, R.

(2006). ¡Ampay, tele!: Niñ@s y adolescentes opinan y juzgan a la televisión peruana. Lima: Veeduría Ciudadana de la Comunicación Social. 
(2003). Atrapadas, sin salida: Imágenes de mujer y de pareja en telenovelas y publicidad. Lima: Veeduría Ciudadana de la Comunicación Social.

Alonso, A. (2008). “Cómo nos enseñan a ser niñas y niños con los juguetes”. Extraída el 22/ VIII/2013 desde http://www.juntadeandalucia.es/averroes/html/adjuntos/2008/06/04/0001/ adjuntos/pdf/socializacion_6.pdf

Amador Pérez, S. (2004). La representación social de la tecnología en mujeres rurales. Los procesos sociocognitivos como fundamento de la relevancia social [Tesis de maestría]. Universidad de las Américas Puebla, Escuela de Ciencias Sociales.

Andina, Agencia Peruana de Noticias

_(2011a, marzo, 25). "Mercado peruano importó US\$87 millones en juguetes el año pasado". Extraída el 2/VII/2013 desde http:/www.andina.com.pe/Espanol/ noticia-mercado-peruano-importo-87-millones-juguetes-ano-pasado-350028.aspx\#. UdNZPrnRbcs

_(2011b, noviembre, 05). "Municipio fiscalizará en Miraflores venta de juguetes tóxicos y orientará al público" Extraída el 2/VII/2013 desde http:/www.andina.com.pe/ Espanol/noticia-municipio-fiscalizara-miraflores-venta-juguetes-toxicos-y-orientara-alpublico-385170.aspx\#.UdNYfbnRbcs

_(2010, junio 17). "Mercado de juguetes en Perú mueve hasta US\$ 80 millones anuales, según Mattel”. Extraída el 2/VII/2013 desde http://www.andina.com.pe/Espanol/noticiamercado-juguetes-peru-mueve-hasta-80-millones-anuales-segun-mattel-301909.aspx\#. UdNZprnRbcs

Babycenter (2012). "Desde la televisión hasta los juguetes, ¿qué hace que los niños sean niños y las niñas sean niñas?”. Extraída el 22/VIII/2013 desde http://espanol.babycenter. $\mathrm{com} /$ a10900112/desde-la-televisi $\% \mathrm{C} 3 \% \mathrm{~B} 3 n$-hasta-los-juguetes-qu $\% \mathrm{C} 3 \% \mathrm{~A} 9$-hace-quelos-ni\%C3\%B1os-sean-ni\%C3\%B1os-y-las-ni\%C3\%B1as-sean-ni\%C3\%B1as-

Badinter, E. (1994). XY la identidad masculina. Bogotá: Norma.

$B B C$ (2013). "En fotos: Princesas de cuentos de hadas con problemas de hoy" Extraída el 22/VIII/2013 desde http://www.bbc.co.uk/mundo/video_fotos/2013/08/130812_galeria princesas_nm.shtml

Bordieu, P. (1988). La distinción. Criterio y bases sociales del gusto. Buenos Aires: Siglo Veintiuno.

Cabanillas, A. (2012, noviembre 10). "Los limeños gastarán S/.1,263 millones en esta Navidad”. Extraída el 21/VIII/2013 desde http://peru21.pe/economia/limenos-gastarans1263-millones-esta-navidad-2102823

Callirgos, J. (1998). Sobre héroes y batallas: Los caminos de la identidad masculina. Lima: Escuela para el Desarrollo, DEMUS. 
Costa, A. (2011, diciembre, 3). "Conoce cuánto cuestan los juguetes de moda y compara alternativas". Extraída el 2/VII/2013 desde http://elcomercio.pe/economia/1342958/ noticia-sepa-cuanto-cuestan-juguetes-moda-compare-alternativas

CONCORTV (2012). “2012 - Encuesta a niños y adolescentes sobre la radio y televisión peruana". Extraída el 22/VIII/2013 desde http://www.concortv.gob.pe/index.php/ estudios/1041-2012-encuesta-a-ninos-y-adolescentes-sobre-la-radio-y-televisionperuana.html

Díaz, A. (2011, diciembre 24). "Diversión es destino: Desde la niñez, juegos y juguetes imponen estereotipos sexistas". Extraída el 22/VIII/2013 desde http://www.jornada.unam. $\mathrm{mx} / 2011 / 12 / 24 /$ politica/002n1pol

El Comercio (2013, mayo, 18). "FOTOS: en Berlín no quieren a Barbie, la acusan de machista e irreal". Extraída el 2/VII/2013 desde http://elcomercio.pe/actualidad/1578273/ noticia-berlin-no-quieren-barbie-acusan-machista-irreal

Ferrer, M. (2007). "Los anuncios de juguetes en la campaña de Navidad". Comunicar, vol. XV, núm. 29, pp. 135-142. Extraída el 21/VIII/2013 desde http://www.revistacomunicar. com/ verpdf.php?numero $=29 \&$ articulo $=29-2007-22$.

Forno, M. (2011). "Reconociendo y Entendiendo la Sexualidad de los y las Adolescentes". Material de clase - VIII Diplomado de Orientadores en Salud Sexual y Salud Reproductiva. Lima: Inppares.

Fuller, N. (2001). Masculinidades: cambios y permanencias. Lima: Fondo Editorial PUCP. Fundación Eduardo Punset (2012). "Mi hijo solo juega con princesas". Extraída el 22/ VIII/2013 desde http://www.fundacionpunset.org/apol/18537/mi-hijo-solo-juega-conprincesas/

Galimberti, G. (2013). "Proyect Toy Stories”. Extraída el 2/VII/2013 desde http://www. gabrielegalimberti.com/projects/toys-2/

Gestión (2012, diciembre, 4). "Cencosud estima un alza del 20\% en la venta de juguetes". Extraída el 2/VII/2013 desde http:/gestion.pe/empresas/cencosud-peru-estima-alza-20venta-juguetes-2053371

Huizinga, J. (1968). Homo Ludens. Buenos Aires: Emecé Editores.

\section{IBOPE TIME}

_(2012). “Consulta de avisos juguetes. Período del 01 octubre al 31 de diciembre. Amas de casa total". Lima.

_(2011). "Consulta de avisos juguetes. Período del 01 octubre al 31 de diciembre. Amas de casa total". Lima. 
La Razón (2013, julio 8). "Barbie, con curvas reales". Extraída el 22/VIII/2013 desde http://www.larazon.com.ar/interesa/Barbie-curvas-reales_0_476100162.html

Mendoza, H. (2012, mayo 11, 18 y 25). "Publicidad y género. ¿De dónde partimos y a dónde vamos?” Ponencia presentada en el Instituto Cultural Peruano Británico. Lima.

Ministerio de la Igualdad, Gobierno de España (2009). "Educando en Igualdad: Pequeño diccionario coeducativo para niños y niñas de primaria”. Extraída el 22/VIII/2013 desde http:// web.educastur.princast.es/proyectos/coeduca/wp-content/uploads/2013/05/Primaria.pdf

Molina, R. (2008). "El juego como medio de socialización”. Extraída el 2/VII/2013 desde http://www.csi-csif.es/andalucia/modules/mod_ense/revista/pdf/Numero_14/REMEDIOS_ MOL INA_2.pdf

Mora, M. (2002). "La teoría de las representaciones sociales de Serge Moscovici". Athenea Digital, núm. 2. Extraída el 22/VIII/2013 desde http://blues.uab.es/athenea/num2/Mora.pdf

Nieto, S. (2003). “Juguetes más sexistas, imposible”. Extraída el 22/VIII/2013 desde http:// www.elmundo.es/cronica/2003/424/1070273711.html

Noticias 24 (2013, enero 29). “¡Insólito! Barbie humana conoce a Ken humano”. Extraída el 22/VIII/2013 desde http://noticias24carabobo.com/entretenimiento/noticia/3523/insolitobarbie-humana-conoce-a-ken-humano-fotos/

Paideia Libre (2003). “Juguetes sexistas y/o bélicos: Preguntas y respuestas”. Extraída el 22/VIII/2013 desde http://www.paideiaescuelalibre.org/

Pérez, L. (2010). "La importancia del juego y del juguete en la socialización”. Extraída el 22/VIII/2013 desde http://suite101.net/article/la-importancia-del-juego-y-del-juguete-enla-socializacion-a28150

Pizarro, N. (1979). "El sujeto y los valores: La sociología de la acción de Alain Touraine". Reis: Revista española de investigaciones sociológicas, núm. 5, pp. 37-54. Extraída el 22/ VIII/2013 desde http://dialnet.unirioja.es/servlet/articulo?codigo=665699

Publimetro Chile (2012, noviembre 26). “Catálogo en Suecia muestra a niños jugando con muñecas y a niñas con armas". Extraída el 22/VIII/2013 desde http://www.publimetro. $\mathrm{cl} /$ nota/mundo/catalogo-en-suecia-muestra-a-ninos-jugando-con-munecas-y-a-ninas-conarmas/x IQlkz! ugwck60CbnoT/

Touraine, A. (1969). Sociología de la acción. Barcelona: Ariel.

Yon Leau, C. (1998). Género y sexualidad. Una mirada de los y las adolescentes de cinco barrios de Lima. Lima: Manuela Ramos. 
YouTube, sitio web.

_(2013a, enero 15). "Max Steel - Max e pantera vs toxzon.mov”. Extraída el 22/VIII/2013 desde http://www.youtube.com/watch?v=8QPK1wezU9Q

_(2013b, mayo 25). "Treehouse Playset / Domek na drzewie - Littlest Pet Shop - Hasbro". Extraída el 22/VIII/2013 desde http://www.youtube.com/watch?v=RATRPsx_Pkw

_(2012a, enero 15). "Rileyon marketing (subtitulado al español)”. Extraída el 15/I/2012 desde http://www.youtube.com/watch?v=VLuwUY4Y2uo

_(2012b, diciembre 10). "Venta de juguetes crecería 12\% en la campaña navideña - primera parte". Extraída el 22/VIII/2013 desde http://www.youtube.com/watch?v=8yCzE0ToP80

_(2012c, diciembre 12). "Venta de juguetes crecería $12 \%$ en la presente campaña navideña - Frecuencia Latina". Extraída el 22/VIII/2013 desde http:/www.youtube.com/watch?v= 5wlAHNqQloc

(2012d, abril 11). "El reclamo de los niños incómodos". Extraída el 21/VIII/2013 desde http://www.youtube.com/watch?v=mnH7LxqEH84

_(2012e, julio 5). "Barbie California Dream house”. Extraída el 22/VIII/2013 desde http:// www.youtube.com/watch? $\mathrm{v}=9 \mathrm{~h} 86 \mathrm{fEdBLdo}$

_(2012f, noviembre 11). “Barbie Sister Cruise Ship”. Extraída el 22/VIII/2013 desde http:// www.youtube.com/ watch?v=1A5xG_xLN6c

(2012g, junio 29). “2011 Barbie Fashionistas Hollywood Divas Commercial”. Extraída el 22/VIII/2013 desde http://www.youtube.com/watch?v=luhPRZmnqB4

_(2012h, octubre 9). “2012 Barbie Fashionistas Endress Closet Commercial”. Extraída el 22/V/2013 desde http://www.youtube.com/watch?v=Ptuel4RMkuY

_(2012i, abril 10). “Barbie Design and dress studio”. Extraída el 22/VIII/2013 desde http:// www.youtube.com/watch?v=L_RwEIdw90g

_(2012j, mayo 29). "Barbie hair braider commercial”. Extraída el 22/VIII/2013 desde http://www.youtube.com/watch?v=cuGTLzryNuk

(2012k, octubre 23). "Barbie Hairtastic Color and Design Salon”. Extraída el 22/VIII/2013 desde http://www.youtube.com/watch?v=KYL8a61ALE8

_(20121, mayo 6). "Barbie pancake teacher English". Extraída el 22/VIII/2013 desde http://www.youtube.com/watch?v=x5MI2JID_VE

_(2012m, junio 27). “Ataque del T Rex Hot Wheels". Extraída el 22/VIII/2013 desde http://www.youtube.com/watch?v=CSx4HlyGrv0

_(2012n, noviembre 5). “HW light speederspinturaradical”. Extraída el 22/VIII/2013 desde http://www.youtube.com/watch?v=dESe8-bzDMs

_(2012o, octubre 20). “HW Ballistik”. Extraída el 22/VIII/2013 desde http://www.youtube. com $/$ watch? $\mathrm{v}=\mathrm{O} \_\mathrm{NhDA} 21 \mathrm{Pyw}$

_(2012p, octubre 17). "Max Steel Serpiente Gigante vs Elementor Ataque Eléctrico". Extraída el 22/VIII/2013 desde http://www.youtube.com/watch?v=XDnNsaZFrUc

_(2012q, agosto 30). "Max Turbo Serra Vs Makino Moto de Ataque”. Extraída el 22/ VIII/2013 desde http://www.youtube.com/watch?v=rrriopxKuEE

_(2012r, octubre 17). “Max Steel Figura Especial”. Extraída el 22/VIII/2013 desde http:// www.youtube.com/watch?v=Guwfgp $5 \mathrm{NjJc}$

_(2012s, mayo 8). "Bonecos do Max Steel”. Extraída el 22/VIII/2013 desde http://www. youtube.com/watch?v=H1tWLQqnAbg

_(2012t, septiembre 6). “Hail Fire - N-Strike Elite - Nerf”. Extraída el 22/VIII/2013 desde 
http://www.youtube.com/watch?v=DaBRUjzRUoU

_(2012u, septiembre 26). “Nuevo Monopoly Millonario”. Extraída el 22/VIII/2013 desde http://www.youtube.com/watch?v=yb-gXZOzZnI

_(2012v, junio 7). "Barbie Fashionistas in the Spotlight (Hollywood Divas, Spanish)". Extraída el 22/VIII/2013 desde http://www.youtube.com/watch?v=3IGL8_QrNnQ

_(2012w, abril 27). "Lalaloopsy Littles, de Bandai”. Extraída el 22/VIII/2013 desde http:// www.youtube.com/watch?v=HTDLpsq1Nkg

_(2011a, diciembre 9). “Los juguetes para esta Navidad”. Extraída el 22/VIII/2013 desde http://www.youtube.com/watch?v=akreHJQijgY

_(2011b, octubre 17). "Barbie Princess Charm School - Royal Princess Bed \& Bath play set". Extraída el 22/VIII/2013 desde http://www.youtube.com/watch?v=X-Pu6hRCgIc

(2011c, octubre 2). "Barbie Parque acuático de perritos comercial". Extraída el 22/ VIII/2013 desde http://www.youtube.com/watch?v=ryYTWgVctzY

_(2011d, octubre 26). "Commercial Hot Wheels Colour Shifters Piranha Attack". Extraída el 22/VIII/2013 desde http://www.youtube.com/watch?v=rh-U7jEYBWg

_(2011e, octubre 30). "Hot Wheels Pista Salto Infernal". Extraída el 22/VIII/2013 desde http://www.youtube.com/watch? $\mathrm{v}=\mathrm{z} 9$ LmCypaU0o\&noredirect $=1$

_(2011f, marzo 8). “Team Hot wheels commercial”. Extraída el 22/VIII/2013 desde http:// www.youtube.com/watch?v=qv5xNm6PF-I

_(2011g, octubre 4). "Hot Wheels Rev Ups". Extraída el 22/VIII/2013 desde http://www. youtube.com/watch?v=2Ee-DhlendM

(2011h, abril 5). "Max Steel Tv Spot 2011: Max Armadura Extrema”. Extraída el 22/ VIII/2013 desde http://www.youtube.com/watch?v=-j5pXrkjICY

_(2011i, septiembre 9). "NL 2011 TVC NERF N Strike vs Vortex 30sec”. Extraída el 22/

VIII/2013 desde http://www.youtube.com/watch?v=cfRsvv_LoC4

_(2011j, enero 8). "Nerf 2011 Commercial - N-Strike Barricade RV-10". Extraída el 22/

VIII/2013 desde http://www.youtube.com/watch?v=9dH5jfN6Vj0

_(2011k, mayo 29). "Nerf N-strike Stampede ECS-50". Extraída el 22/VIII/2013 desde http://www.youtube.com/watch? $\mathrm{v}=$ fviDyDASHDY

_(20111, abril 27). "NERF triple blaster". Extraída el 22/VIII/2013 desde http://www. youtube.com/watch? $=9$ gjPJNjsf1A

_(2011m, agosto 30). “Barbie When I grow up Español”. Extraída el 22/VIII/2013 desde http://www.youtube.com/watch?v=uElRx1IZCuk

_(2010a, noviembre 28). "Lo último en juguetes para esta Navidad". Extraída el 22/ VIII/2013 desde http://www.youtube.com/watch?v=FUIkPIF-UP0

_(2010b, diciembre 29). “Commercial Hasbro Monopoly Perú”. Extraída el 22/VIII/2013 desde http://www.youtube.com/watch?v=2-hRZ7k2k-c

_(2010c, octubre 6). "Blythe Loves LITTLEST PET SHOP”. Extraída el 22/VIII/2013 desde http://www.youtube.com/watch?v=GzlNGi5dvqc

_(2008, agosto 29). "Los niños hacen lo que ven”. Extraída el 21/VIII/2013 desde http:// www.youtube.com/watch?v=D1wuvD4IWKs 